\title{
RECONFIGURING THEOLOGY:
}

\section{A NEED FOR ORGANIC INTELLECTUALS AND A CHALLENGE TO EPISTEMIC PRIVILEGE}

\section{Guest Editorial}

\author{
Itumeleng Daniel Mothoagae \\ Department of Biblical and Ancient Studies \\ University of South Africa
}

The articles published in this issue of Scriptura were subjected to a rigorous peer review process in accordance with the required academic standard set for this journal. Authors of the African continent and the Diaspora in various fields of the humanities have contributed to this special issue that emerged partly from the conference, Voice and Voicelessness: Religion and Theology beyond the Ivory Tower (how do we make our thinking relevant in academia and the community?), hosted by the University of South Africa in collaboration with the Institute for Diasporan Culture, New York, and Berkeley College, New York, from 3 to 5 October 2012.

Theology as an academic discipline in South Africa has contributed scientifically to public discourse both negatively and positively. The contribution of theology enabled the discipline to reconfigure itself and to raise issues about organic intellectuals and as a result challenge epistemic privilege that characterised the country at the time. The changing situation in which South Africa finds itself in the post-apartheid era has raised a number of questions relating to the relevance of theology, its interlocutors and epistemic privilege that seem to define South African institutions. The movement from critical engagement with the socio-economic, socio-political conditions of the Black majority, as well as the emphasis on Eurocentric methodology, has contextualised theology within the paradigm of an ivory tower. As a result questions surrounding epistemic privilege emerge. To illustrate the challenges that theology is facing in post-apartheid South Africa regarding reconfiguring and organic intellectuals, Grosfoguel in his article (2013) makes the following assertions regarding epistemic privilege.

But this provincialism is disguised under a discourse about "universality." The pretension is that the knowledge produced by men of these five countries has the magical effect of universal capacity, that is, their theories are supposed to be sufficient to explain the social/historical realities of the rest of the world. As a result, our job in the Westernized university is basically reduced to that of learning these theories born from the experience and problems of a particular region of the world (five countries in Western Europe) with its own particular time/space dimensions and "applying" them to other geographical locations even if the experience and time/space of the former are quite different from the latter. These social theories based on the social-historical experience of men of five countries constitute the foundation of the Social Sciences and the Humanities in the Westernized universities today. The other side of this epistemic privilege is epistemic inferiority. Epistemic privilege and epistemic inferiority are two sides of the same coin. The coin is called epistemic racism/sexism (2013:74-75). 
The questions of reconfiguring theology, organic intellectuals and epistemic privilege are important in unravelling the changing conditions in which theology finds itself South Africa. Moreover, it indicates that there had been processes that led to a justification for the so-called religion and theology in an ivory tower today in post-apartheid theological scholarship. Some of these processes are critically engaged in this special edition. This special issue incorporates Multi. Inter and Trans-disciplinary research and discourse. Contributors addres the issues of ministerial formation, masculinity, gender, Afrikology, Ubuntu, policy and citizenship.

Amanze argues that it is imperative for the Church in Africa to concretise some of the characters found in theBible. He does so by showing how Prophet Joshua and Synagogue Church of All Nations have taken the message of the prophets very seriously. Buntu locates the challenges that face Africans as the need to reclaim a collective sense of Self which is deemed necessary for authentic change. Chimhanda seems to be in agreement with Amanze's assertion that theology and spirituality should mutually influence one another to make theology relevant and coherent to the community of faith it serves. Dolamo further challenges the notion of epistemic privilege by arguing succinctly that culture and religion are not static entities, and that in this postmodernist and globalising world ubuntu could be enriched by taking cognisance of the values and principles of other cultures and religions.

Masoga raises the issue of relevance of theology done as well as the current challenges that the Christian communities are facing. Mothoagae looks at the marginalised black majority and the need for Black Liberation Theology to challenge the status quo. Naidoo asserts that the time of theological training is crucial for ministers to encourage a mature development of occupational and personal identity and foster a coherent understanding of their role and function in ministry, while Nzewi and Groenewald draw from institutionalism and policy studies and argue that religion and theology belong in the public sphere. Segalo interrogates the oppressive structures that continue to perpetuate the silence of women. As a result women are unable to participate actively in various ways of reclaiming their voices and power. Shaw-Taylor compares the Christ Apostolic Church (CAC) and the early Church. She discusses the transnational significance it holds for the Diaspora where women's issues are placed at the forefront. Slater in her article grapples with gender equality, integrity of every human person and maintains that gender equality had become an incentive for gender-based violence. Togarasei explores how culture, traditional religion, colonial attitudes and Christianity can help in the construction of dangerous masculinities in Botswana.

It remains vital to reflect seriously and engage in dialogue on epistemic privilege that continues to define what knowledge is. The recent media reports on the mutilation and destruction of human bodies particularly of children and the vulnerable, as well as the service delivery protests, compels the church and theologians to occupy the space so as to give meaning and voice to these horrible acts. Failure to occupy the void raises questions around the relevance of the church and theology in the public space. Themes of voice and voicelessness will forever be present, making them part of the always-present prophetic voice of the church and theologians.

Reference: Grosfoguel, R 2013. "The Structure of Knowledge in Westernized Universities: Epistemic Racism/Sexism and the Four Genocides/Epistemicides of the Long 16th Century". Human Architecture: Journal of the Sociology of Self-Knowledge, XI, Issue 1, Fall 2013:73-90. 